\title{
Mortality Assessment of Botanical Oils on Anastrepha fraterculus (Wiedemann, 1830) Applied in Fruits Under Laboratory Conditions
}

\author{
Dahise Brilinger ${ }^{1}$, Cleiton L. Wille ${ }^{1}$, Joatan M. da Rosa ${ }^{1}$, Cláudio R. Franco ${ }^{1}$ \& Mari Inês C. Boff ${ }^{1}$ \\ ${ }^{1}$ Departamento de Agronomia, Centro de Ciências Agroveterinárias, Universidade do Estado de Santa Catarina, \\ Lages, Brazil \\ Correspondence: Dahise Brilinger, Universidade do Estado de Santa Catarina, Centro de Ciências \\ Agroveterinárias, Av. Luiz de Camões 2090, Conta Dinheiro, CEP 88.520-000, Lages, Brazil. Tel: \\ 55-489-8825-0954. E-mail: dahise_b@hotmail.com
}

Received: February 1, 2019

Accepted: April 2, 2019 Online Published: June 15, 2019

doi:10.5539/jas.v11n8p287

URL: https://doi.org/10.5539/jas.v11n8p287

\begin{abstract}
The objective of this study was to evaluate the effect of botanical oils on adult mortality and oviposition repellency of Anastrepha fraterculus in peach, apple and red cattley guava fruits. The fruits were treated by the dip method for 15 seconds with botanical oils of Ruta graveolens (0.05\%), Cymbopogon citratus (1\%), Cymbopogon winterianus (10\%), Carapa guianensis $(25 \%)$ and distilled water was used as a control. The experiments were carried out in a completely randomized design with twenty replicates. After being treated, the fruits were dried at room temperature, placed in separate plastic containers $(750 \mathrm{~mL})$ and transferred to a room at $25 \pm 2{ }^{\circ} \mathrm{C}$. Each fruit was exposed to two fruit fly couples for 48 hours. After this period, the amount of dead insects was recorded. On apple fruits kept in containers with sterilized vermiculite, the effect of the treatments on A. fraterculus biology was evaluated for 36 days, and data were collected on the amount of pupae in the second generation. C. winterianus oil presented mortality rates of 100 and $80 \%$ of adults in peach and apple fruits, respectively. C. citratus oil caused a significantly different mortality rate compared to the control in peach fruits, whereas $C$. guianensis oil caused $A$. fraterculus mortality in red cattley guava and apple fruits. The mortality of $A$. fraterculus in fruits treated with $R$. graveolens oil did not differ from the control treatment. The botanical oils of $C$. winterianus and C. guianensis protected apple fruits by preventing $A$. fraterculus proliferation, and there was a significant reduction of the amount of pupae in the second generation. Botanic oils presented potential for suppression of fruit flies; however, further studies are necessary to test and make them feasible under field conditions.
\end{abstract}

Keywords: Anastrepha fraterculus, botanical oils, fruit fly, mortality

\section{Introduction}

The world trade of fruits and vegetables has grown in recent years, partly because people have been changing their eating habits and adopting healthy lifestyles (Colombia, 2016). Brazil is the third largest producer of fruits, with annual production of more than 43 million tons (Treichel, Kist, dos Santos, de Carvalho, \& Beling, 2016). Fruit growing is an activity with significant economic profitability in the southern region of Brazil, (Monteiro, 2004) and it can be considered as an important source of income, particularly for small farmers.

The Southern region stands out as the main apple (Malus domestica Borkh.) producer of Brazil, accounting for approximately $98 \%$ of the national production (Brasil, 2017). Another important tree in this region is peach (Prunus persica L.), which is grown in an area of 17000 hectares (Brasil, 2016a). Close to these commercial orchards are native fruits trees originating from natural forest remnants, and one of the most common is the red cattley guava (Psidium cattleianum Sabine.), which is considered as a primary host of fruit flies (Zucchi, 2008).

The occurrence of the South American fruit fly Anastrepha fraterculus Wied. (Diptera: Tephritidae) is one of the main barriers to the production of fresh fruits in southern Brazil (Nava \& Botton, 2010; Machota Junior, Bortoli, Cavalcanti, Botton, \& Grützmacher, 2016). The damage of A. fraterculus can be observed shortly after oviposition, when unripen fruits can grow deformed. In ripe fruits, the larvae consume the pulp (Nava \& Botton, 2010), and the punctures performed by the females open small holes in the epidermises, facilitating the entry of pathogens and inducing the premature fall of fruits (Schlesener, Nunes, Cordeiro, Gotts-Chalk, \& Garcia, 2014; Machota Junior et al., 2016). A. fraterculus females generally prefer to oviposit in fruits that are mature or nearly 
mature. In mature fruits, bark texture and pulp consistency (Nunes et al., 2015b), sugar contents (Lorscheiter, Redaelli, Botton, \& Pimentel, 2012) and brix degree (Rattanapun, Amornsak, \& Clarke, 2009) are predominant factors for fruit fly oviposition behavior. According to Rattanapun et al. (2009), mature fruits with higher sugar content are more suitable for larval development, as they ensure a higher survival rate and a shorter development period. In green fruits, larvae of Tephritidade rarely complete their development. However, Fontellas-Brandalha and Zucoloto (2004) reported that fruit flies perform oviposition in green fruits in an attempt to ensure offspring survival.

Control of fruit flies in Brazil is commonly performed by spraying insecticides, mainly organophosphates and pyrethroids. According to the Ministry of Agriculture, Livestock and Supply (MAPA), organophosphate insecticides authorized for control of fruit flies in conventional apple orchards are phosmet, malathion, dimetothione, fenitrothione and metidationa, while only malathion is allowed for use in peach orchards (Brasil, 2018). These insecticides are considered to be highly harmful to natural enemies, especially to predatory mites and parasitoids (Nava \& Botton, 2010). However, inappropriate use may lead to environmental pollution and damage to human health (Khalili-Zanjani, Yamini, Yazdanfar, \& Shariati, 2008). Another important point is that the use of organophosphate insecticides is limited in sustainable fruit production systems such as Integrated Fruit Production (IFP) and banned in Organic Fruit Production (OFP) (Botton, Arioli, Machota Junior, \& Nunes, 2016).

In addition, the 2016 report of the Agrochemical Residual Analysis Program (PARA), managed by the National Agency for Sanitary Surveillance (ANVISA), showed the results of an analysis of 12051 samples of 25 different vegetables collected in 27 states; $19.7 \%$ of them presented unsatisfactory results, indicating that the percentage of pesticides was above the tolerance level (Brasil, 2016b). With regard to apple fruits, $10.6 \%$ of the samples were irregular in terms of levels of pesticides allowed for insect pest management in apple orchards. Among the irregular samples, $9.0 \%$ were considered unsatisfactory because they had residues of non-authorized insecticides for apple orchards, such as esfenvalerate (Pyrethroid) (Brasil, 2016b).

Thus, the worldwide concern over the use of agrochemicals for food production has led to an ever-increasing demand for research on new alternative methods for fruit fly management. As natural substances, botanic oils can be a viable alternative for control of insect pests. Botanical substances have advantages compared to synthetic insecticides, e.g., a lower chance of insect resistance development and a shorter half-life in the environment (Azevedo, dos Santos, Nere, da Silva Moura, \& Gurgel, 2013; Marangoni, de Moura, \& Garcia, 2013). Many botanical substances can have insecticidal activity which may adversely affect the biology of fruit flies (Nunes, Boff, dos Santos, Franco, \& da Rosa, 2015; Daniel, 2014) by causing toxicity (Ghabbari et al., 2018; Daniel, 2014) which results in adult mortality (Vásquez-Morales et al., 2015). In addition, studies carried out by Greany et al. (1983) showed that citrus peel oils were toxic to A. fraterculus neonate larvae. Ruiz et al. (2014) found that citrus extracts (limonene and citral) were toxic to eggs and larvae of A. fraterculus. Testing essential oils of Baccharis dracunculifolia and Pinus elliottii, Ovideo et al. (2018) reports levels of 100\% mortality of $C$. capitata pupae and $84 \%$ reduction of $A$. fraterculus adult emergence.

Although there has been previous research, there is a need for botanical substances which are effective, persistent and practical to use. The present research was therefore undertaken to investigate the effect of botanical substances on oviposition repellency and mortality of $A$. fraterculus adults in peach, apple and red cattley guava fruits under laboratory conditions.

\section{Method}

The experiment was carried out in a laboratory using botanical oils of rue (Ruta graveolens), lemon grass (Cymbopogon citratus), citronella (Cymbopogon winterianus) and andiroba (Carapa guianensis). Andiroba, lemon grass and citronella oils were purchased from a pharmacy. Rue oil was obtained from fresh leaves using a Clevenger apparatus for essential oil extraction. The botanical oils were diluted in distilled water and stored in glass bottles protected from direct sunlight (Nunes et al., 2015a).

Peach fruits (Premier cultivar) were purchased in organic production orchards. The fruits of apple (Fuji cultivar) and fruits of red cattley guava (Psidium cattleyanum var. cattleyanum) were purchased in non-commercial orchards of the State University of Santa Catarina. The fruits were previously bagged using nonwoven fabric after flowering to avoid natural infestation of fruit flies in the field. All fruits were harvested at physiological maturation. 


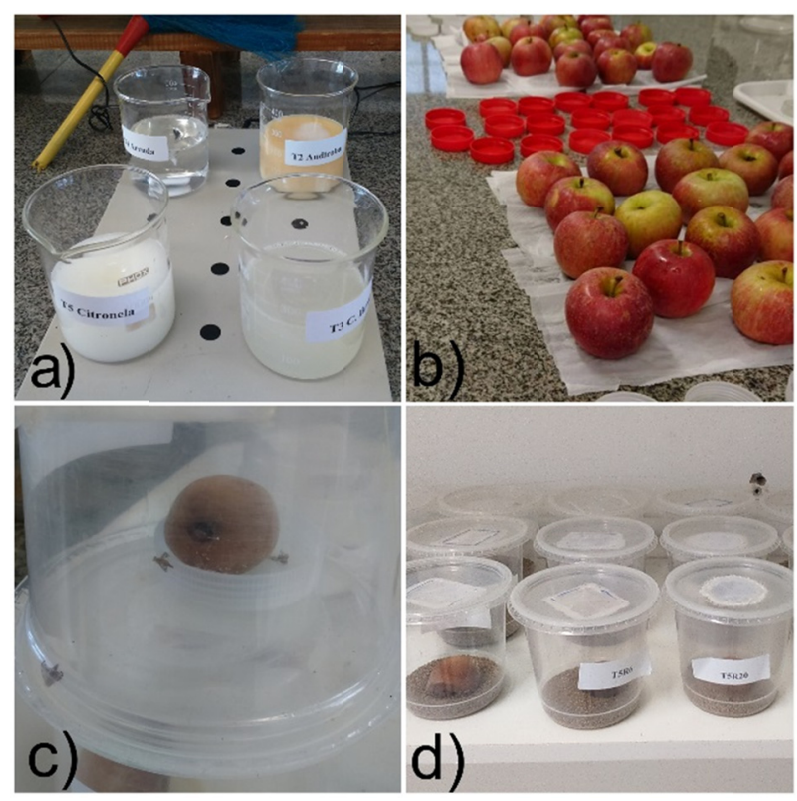

Figure 1. a) botanic oils; b) apple fruits after immersion drying at room temperature; c) peach fruits placed in a transparent plastic container with two couples of A. fraterculus; d) fruits in containers with vermiculite

The experiments were set up in a completely randomized design with five treatments and twenty replicates. The treatments consisted of: a) $25 \%$ andiroba oil; b) $0.05 \%$ rue oil; c) $1 \%$ lemon grass oil; d) $10 \%$ citronella oil and e) distilled water (Figure 1a).

Each fruit was immersed for 15 seconds in the oils or in distilled water (control treatment) and dried at room temperature for two hours (Nunes et al., 2015a) (Figure 1b). The fruits were then placed in a transparent $750 \mathrm{~mL}$ plastic container containing $A$. fraterculus diet (sugar, wheat germ and yeast extract (Bionis YE MF®) in a 3:1:1 ratio) and a cotton wad soaked in distilled water. Two couples of $A$. fraterculus (15 to 20 days old) were released into each container and maintained in a temperature-controlled room $\left(25 \pm 2{ }^{\circ} \mathrm{C}\right.$ and $\left.60 \pm 10 \% \mathrm{RH}\right)$ for 48 hours (Figure 1c). The adults of $A$. frateculus in use are from fruit fly rearing at UDESC/CAV.

Adult mortality was accessed 48 hours after exposure. The effect of treatments on $A$. fraterculus biology was evaluated in the apple fruits. These fruits were individualized in containers with vermiculite (Figure 1d) and kept in a temperature-controlled room $\left(25 \pm 2{ }^{\circ} \mathrm{C}\right.$ and UR $\left.60 \pm 10 \%\right)$ for 36 days. Afterwards, number of pupae of the second generation was accessed by sieving the vermiculite. The collected data were transformed into $(x+1)^{1 / 2}$ and submitted to analysis of variance (ANOVA). Duncan multiple comparison test was applied, as ANOVA indicated at least one significant difference among treatments $(P>0.05)$. Statistical analyses were made using SAS 9.0 (SAS Institute, 2002).

\section{Results and Discussion}

The peach fruits treated with lemon grass and citronella oils had significant adult mortality of $62 \%$ and $100 \%$, respectively (Table 1). The red cattley guava and apple fruits treated with andiroba and citronella oil had the highest mortality rates: $62.5 \%$ and $80 \%$ in apples, respectively, and both oils caused $20 \%$ mortality in red cattley guava fruits (Table 1). Apple fruits treated with any botanical oils had a significant reduction in the number of pupae compared to the control treatment (Table 2). 
Table 1. Mortality (Mean \pm SE) and total mortality (M\%) of Anastrepha fraterculus adults (Diptera: Tephritidae) exposed to red cattley guava, apple and peach fruits treated with botanical oils under laboratory conditions $\left(25 \pm 2{ }^{\circ} \mathrm{C}\right.$ and $\left.\mathrm{RH} 60 \pm 10 \%\right)$

\begin{tabular}{|c|c|c|c|c|c|c|}
\hline \multirow{2}{*}{ Treatment } & \multicolumn{2}{|c|}{ Red cattley guava } & \multicolumn{2}{|c|}{ Apple } & \multicolumn{2}{|c|}{ Peach } \\
\hline & Mortality & $\mathrm{M} \%$ & Mortality & $\mathrm{M} \%$ & Mortality & $\mathrm{M} \%$ \\
\hline Carapa guianensis $(25 \%)$ & $0.80 \pm 0.17 \mathrm{a}$ & 20 & $2.50 \pm 0.31 \mathrm{a}$ & 62.5 & $0.30 \pm 0.05 \mathrm{c}$ & 7.5 \\
\hline Ruta graveolens $(0.05 \%)$ & $0.10 \pm 0.06 \mathrm{~b}$ & 2.5 & $0.20 \pm 0.09 \mathrm{~b}$ & 5.0 & $0.25 \pm 0.05 \mathrm{c}$ & 6.2 \\
\hline Cymbopogon citratus (1\%) & $0.30 \pm 0.12 \mathrm{~b}$ & 7.5 & $0.20 \pm 0.11 \mathrm{~b}$ & 5.0 & $2.50 \pm 0.07 \mathrm{~b}$ & 62.5 \\
\hline Cymbopogon winterianu $(10 \%)$ & $0.80 \pm 0.26 \mathrm{a}$ & 20 & $3.20 \pm 0.28 \mathrm{a}$ & 80 & $4.00 \pm 0.00 \mathrm{a}$ & 100 \\
\hline Control (distilled water) & $0.05 \pm 0.05 \mathrm{~b}$ & 1.2 & $0.15 \pm 0.08 \mathrm{~b}$ & 3.7 & $0.10 \pm 0.03 \mathrm{c}$ & 2.5 \\
\hline
\end{tabular}

Note. Means followed by the same letter in each column do not differ statistically by Duncan's test (P $>0.05)$.

In that case, the fruits treated with andiroba oil presented only 0.25 pupae while no pupa was found in fruits treated with citronella oil. This reduction may be due to egg mortality during the incubation period or a deterrent effect that can be caused by the oils, either preventing females from approaching the fruits by repelling them or by physically hindering their oviposition. As an example, Nguyen et al. (2007) found that adults of Bactrocera tryoni (Diptera: Tephritidae) avoided landing and ovipositing in fruits treated with mineral oil. On the other hand, Hidayat, Heather and Hassan (2013) showed that vegetable oils did not repel B. tryoni but acted as oviposition deterrents because a slippery layer was formed on the fruit surface.

Table 2. Amount of Anastrepha fraterculus (Diptera: Tephritidae) pupae (Mean $\pm \mathrm{SE}$ ) found in apple fruits treated with botanical oils under laboratory conditions $\left(25 \pm 2{ }^{\circ} \mathrm{C}\right.$ and $\left.\mathrm{RH} 60 \pm 10 \%\right)$

\begin{tabular}{ll}
\hline Treatment & Amount of pupae \\
\hline Carapa guianensis $(25 \%)$ & $0.25 \pm 0.16 \mathrm{a}$ \\
Ruta graveolens $(0.05 \%)$ & $1.95 \pm 0.51 \mathrm{~b} \mathrm{c}$ \\
Cymbopogon citratus $(1 \%)$ & $1.40 \pm 0.61 \mathrm{~b}$ \\
Cymbopogon winterianu $(10 \%)$ & $0.00 \pm 0.00 \mathrm{a}$ \\
Control (distilled water) & $2.85 \pm 0.44 \mathrm{c}$ \\
\hline
\end{tabular}

Note. Means followed by the same letter do not differ statistically by Duncan's test $(\mathrm{P}>0.05)$.

The seeds of andiroba (C. guianensis) contain substances called limonoids, which have proven antifeedant effect on insects (Ambrozin et al., 2006). Rosa, Boff, Gonçalves, Boff, and Nunes (2013) found fruit fly repellence of andiroba oil using traps in a field experiment. In a similar experiment to the one conducted in the present study, Nunes et al. (2015a) found mortality of adults and larvae when pear fruits (Pyrus communis) were treated with andiroba oil and supplied to A. fraterculus flies. Mortality of $A$. fraterculus in fruits treated with andiroba oil differed from the control treatment for the red cattley guava and apple fruits (Table 1). This might have occurred due to a repellence effect caused by the oil adhered to the fruit surface.

According to Farias, de Barros, Alves, and da Gloria (2009), andiroba oil is effective on larvae of Musca domestica (Diptera: Muscidae), as it inhibits the emergence of adults. Freire, Brito-Filha and Carvalho-Zilse (2006) reported that andiroba oil inhibits oviposition of phorid flies (Diptera: Phoridae).

Adult mortality of $A$. fraterculus in fruits treated with rue oil was significantly lower than the rates in the other treatments (Table 1). However, Majdoub, Dhen, and Salaheddine Souguir (2014) reported that the essential oil of rue presented insecticidal activity on the Tribolium castaneum (Coleoptera: Tenebrionidae) beetle. In toxicity bioassays, Ghabbari et al. (2018) found that exposure of Ceratitis capitata (Diptera: Tephritidae) to rue extract, resulted in $100 \%$ adult mortality. In addition, Teixeira (2009) showed that rue extract applied to apple fruits significantly reduced the amount of $A$. fraterculus pupae. Nevertheless, in the present study, there was no significant reduction in the number of pupae when this oil was applied to apple fruits.

Lemon grass oil caused $A$. fraterculus mortality only when the oil was applied to peach fruits (Table 1). This effect may be due to the characteristic of the hairy epidermis of peach fruits. This physical constitution of the epidermis may cause peach fruits to accumulate more oil on their surfaces. Similarly, Andrade, de Oliveira, de Moura Lima, de Santana, and Breda (2013) found that lemon grass oil was repellent and caused reduced 
proliferation of Aphis gossypi nymphs in cotton plants. Lima et al. (2008) reported that lemon grass essential oil was effective as an antifeedant to Brevicorine brassicae (Hemiptera: Aphididae) aphid under laboratory conditions.

The lemon grass oil applied to apples caused a reduction in the amount of pupae compared to the control. This might have been due to a repellent effect of the oil, which hindered oviposition. Soares, de Lemos, Cardoso, Medeiros, and Araújo (2011) also found that lemon grass showed insecticidal activity on Thyrinteina arnobia (Lepidoptera: Geometridae), causing $100 \%$ mortality of larvae.

Adults of A. fraterculus exposed to fruits treated with citronella (at 10\% concentration) had up to $100 \%$ mortality (Table 1). Pinheiro et al. (2013) found a similar mortality rate in adults of Myzus persicae (Hemiptera: Aphididae), and nymphs of Frankliniella schultzei (Thysanoptera: Thripidae) when the oil (at $1 \%$ concentration) was sprayed on leaves of cabbage and common bean in the laboratory. Bueno and Andrade (2010) stated that citronella oil repels the mosquito Aedes albopictus (Diptera: Culicidae). Additionally, Ferreira et al. (2014) also reported that citronella oil presented a repellent effect on Stomoxys calcitrans (Diptera: Muscidae) stable flies.

Egg oviposition reduction resulting from a citronella repellent effect was found by Brito (2015) in adults of Tribolium castaneum. Silva, Castro, Silva, Lima, and Oliveira (2014) also found that oviposition of Callosobruchus maculatus (Coleoptera: Chrysomelidae) was inhibited when citronella was applied to cowpea beans (Vigna unguiculata). According to Oliveira (2014), the lowest rates of $A$. fraterculus infestation in guava fruits were found when citronella oil was used. These authors mentioned that the odors released by the oils can negatively affect females at the time of oviposition. In addition, the ovicidal and larvicidal effect of citronella oil was also reported by Colpo, Jahnke, and Füller (2014) in a laboratory study with Grapholita molesta (Lepidoptera: Tortricidae).

The significant difference between adult mortality rates of $A$. fraterculus in peach fruits treated with citronella oil $(100 \%)$ and the high mortality rate in fruits treated with lemon grass oil $(62.5 \%)$ is possibly due to the content of secondary metabolites present in each botanical oil. Carriconde, Mores, Fritschen, and Cardozo Júnior (1995), and Füller (2008) reported that the insecticidal activity of lemon grass and citronella oil is due to the presence of citral and geraniol, respectively. Oliveira et al. (2011) also found that geraniol plays an important role in the insecticidal activity of citronella oil.

The significant reduction in the amount of pupae found in apple fruits treated with citronella and andiroba oil is possibly associated with oviposition repellency and adult mortality. According to Table 1, for both citronella oil and andiroba oil, adult mortality of $A$. fraterculus was significantly higher than in the other treatments. Although the larval stage has not been evaluated, the stages prior to the pupal stage (egg and larvae) may have been affected by either the release of inhibitory compounds or, as Nunes et al. (2015a) pointed out, by the oily film formed after immersion of the fruits, which can interfere with oviposition. According to Daniel (2014), females of the cherry fruit fly, Rhagoletis cerasi (Diptera: Tephritidae), spent much more time to oviposit in fruits treated with rapeseed oil (Brassica napus). This behavior is due to the fact that vegetable oils create a slippery surface (Hidayat, Heather, \& Hassan, 2013) which consequently affects oviposition.

Given the inherent need to seek less residual options for pest control, botanical oils are a promising alternative for protecting crops with fruit susceptible to pest damage. In addition, botanical oils can be incorporated into integrated pest management plans of each plant species of interest, especially in organic crops for control of fruit flies.

\section{Conclusion}

Citronella oil has a lethal effect on adults of $A$. fraterculus and prevents oviposition in peach, apple and red cattley guava fruits.

Andiroba oil causes adult mortality of A. fraterculus when applied in peach, apple and red cattley guava. Also, it inhibits oviposition in apple fruits.

Lemon grass and rue grass oils do not cause significant mortality nor inhibit oviposition of $A$. fraterculus when compared to the control treatment.

\section{References}

Ambrozin, A. R. P., Leite, A. C., Bueno, F. C., Vieira, P. C., Fernandes, J. B., Bueno, O. C., ... Bacci Jr, M. (2006). Limonoids from andiroba oil and Cedrela fissilis and their insecticidal activity. Journal of the Brazilian Chemical Society, 17(3), 542-547. https://doi.org/10.1590/S0103-50532006000300017 
Andrade, L. H. de, de Oliveira, J. V., de Moura Lima, I. M., de Santana, M. F., \& Breda, M. O. (2013). Efeito repelente de azadiractina e óleos essenciais sobre Aphis gossypii Glover (Hemiptera: Aphididae) em algodoeiro. Revista Ciência Agronômica, 44(3), 628-634. https://doi.org/10.1590/S1806-669020130003 00027

Azevedo, F. R., dos Santos, C. A. M., Nere, D. R., da Silva Moura, E., \& Gurgel, L. S. (2013). Inseticidas vegetais no controle de Anastrepha spp. (Diptera: Tephritidae) em pomar de goiaba. Holos, 4, 77-86. https://doi.org/10.15628/holos.2015.3190

Brasil. (2016a). Produção Agrícola Municipal: Culturas temporárias e permanentes. Instituto Brasileiro de Geografia e Estatística, Rio de Janeiro, RJ. Retrieved March 18, 2018, from https://biblioteca.ibge.gov.br/ visualizacao/periodicos/66/pam_2016_v43_br.pdf

Brasil. (2016b). Programa de análise de resíduos de agrotóxicos em alimentos: Relatório das análises de amostras monitoradas no período de 2013 a 2015. Agência Nacional de Vigilância Sanitária, Brasília, GO.

Brasil. (2017). Levantamento Sistemático da Produção Agrícola. Instituto Brasileiro de Geografia e Estatística, Rio de Janeiro, RJ.

Brasil. (2018). Sistema de Agrotóxicos e Fitossanitários. Ministério da Agricultura, Pecuária e Abastecimento, Brasília, GO. Retrieved March 18, 2018, from http://agrofit.agricultura.gov.br/agrofit_cons/principal_ agrofit_cons

Brito, A. S. D. (2015). Atividade inseticida e repelência de óleos essenciais em Tribolium castaneum herbst (Coleoptera: Tenebrionidae) (Doctoral dissertation, Universidade Federal Rural de Pernambuco, Serra Talhada, Brazil).

Botton, M., Arioli, C. J., Machota Junior, R., \& Nunes, M. Z. (2016). Moscas-das-frutas na fruticultura de clima temperado: situação atual e perspectivas de controle através do emprego de novas formulações de iscas tóxicas e da captura massal. Embrapa Uva e Vinho-Artigo em periódico indexado (ALICE).

Bueno, V. S., \& Andrade, C. F. S. (2010). Avaliação preliminar de óleos essenciais de plantas como repelentes para Aedes albopictus (Skuse, 1894) (Diptera: Culicidae). Revista Brasileira de Plantas Medicinais, 12. https://doi.org/10.1590/S1516-05722010000200014

Carriconde, C., Mores, D., Fritschen, M. V. \& Cardozo Júnior, E. L. (1995). Plantas medicinais e alimentícias. Centro Nordestino de Medicina Popular: Universidade Federal Rural de Pernambuco, 1, 63-5.

Colombia. (2016). Información Hortifrutícola. Asociación Hortifrutícola de Colombia, Bogotá. Retrieved February 10, 2018, from http://www.asohofrucol.com.co/interna.php? cat=3\&scat=45\&act=1

Colpo, J., Jahnke, S. M., \& Füller, T. N. (2014). Potencial inseticida de óleos de origem vegetal sobre Grapholita molesta (Busck) (Lepidoptera: Tortricidae). Revista Brasileira de Plantas Medicinais, 16(2), 182-188. https://doi.org/10.1590/S1516-05722014000200003

Daniel, C. (2014). Rhagoletis cerasi: Oviposition reduction effects of oil products. Insects, 5(2), $319-331$. https://doi.org/10.3390/insects5020319

Farias, M. P. O., de Barros, F. N., Alves, L. C., \& da Gloria, M. A. (2009). Eficácia do óleo da semente de andiroba (Carapa guianensis) sobre larvas de Musca domestica (Diptera: Muscidae) por meio do teste de imersão. Rev. Inst. Med. Trop. S. Paulo, 46(2), 97-101.

Ferreira, J. T., Silvano, F. E., Ferreira, H. A. M., do Carmo Nascimento, B. D., Lampert, H. M., Campos, L. F., ... Oliveira, J. E. Z. (2014). Avaliação do capim citronela e da homeopatia em populações de insetos picadores-sugadores em equinos no IF sudeste MG (Vol. 1, No. 1). V Simpósio de Pesquisa e Inovação/IV Seminário de Iniciação Científica do IF Sudeste MG-Câmpus Barbacena.

Fontellas-Brandalha, T. M. L., \& Zucoloto, F. S. 2004. Selection of oviposition sites by wild Anastrepha obliqua (Macquart) (Diptera: Tephritidae) based on the nutritional composition. Neotropical Entomology, 33(5), 557-562. https://doi.org/10.1590/S1519-566X2004000500003

Freire, D. D. C. B., Brito-Filha, C. R. D. C., \& Carvalho-Zilse, G. A. (2006). Effect of andiroba (Carapa sp.) and copaiba's (Copaifera sp.) vegetable oils on phorides, hives's prague (Diptera: Phoridae) in Central Amazonia. Acta Amazônica, 36(3), 365-368. https://doi.org/10.1590/S0044-59672006000300012

Füller, T. N. (2008). Caracterização fenotípica, fitoquímica e molecular de populações de Elionurus sp. Humb. \& Bompl ex Willd (capim-limão) (Master's thesis, Universidade Federal do Rio Grande do Sul, Rio Grande do Sul, Beasil). Retrieved from https:/www.lume.ufrgs.br/handle/10183/15451 
Ghabbari, M., Guarino, S., Caleca, V., Saiano, F., Sinacori, M., Baser, N., ... Verde, G. L. (2018). Behavior-modifying and insecticidal effects of plant extracts on adults of Ceratitis capitata (Wiedemann) (Diptera Tephritidae). Journal of Pest Science, 91(2), 907-917. https://doi.org/10.1007/s10340-018-0952-6

Greany, P. D., Styer, S. C., Davis, P. L., Shaw, P. E., \& Chambers, D. L. (1983). Biochemical resistance of citrus to fruit flies. Demonstration and elucidation of resistance to the Caribbean fruit fly, Anastrepha suspensa. Entomologia Experimentalis Applicata, 34, 40-50. https://doi.org/10.1111/j.1570-7458.1983.tb03288.x

Hidayat, Y., Heather, N., \& Hassan, E. (2013). Repellency and oviposition deterrence effects of plant essential and vegetable oils against female Queensland fruit fly Bactrocera tryoni (Froggatt) (Diptera: Tephritidae). Australian Journal of Entomology, 52(4), 379-386. https://doi.org/10.1111/aen.12040

Khalili-Zanjani, M. R., Yamini, Y., Yazdanfar, N., \& Shariati, S. (2008). Extraction and determination of organophosphorus pesticides in water samples by a new liquid phase microextraction-gas chromatography-flame photometric detection. Analytica Chimica Acta, 606(2), 202-208. https://doi.org/ 10.1016/j.aca.2007.11.032

Lima, R., das Graças Cardoso, M., Moraes, J., Vieira, S., Melo, B., \& Filgueiras, C. (2008). Composição dos óleos essenciais de Anis-estrelado Illicium verum L. e de Capim-limão Cymbopogon citratus (DC.) Stapf: Avaliação do Efeito Repelente sobre Brevicoryne brassicae (L.) (Hemiptera: Aphididae). BioAssay, 3. https://doi.org/10.14295/BA.v3.0.56

Lorscheiter, R., Redaelli, L. R., Botton, M., \& Pimentel, M. Z. 2012. Caracterização de danos causados por Anastrepha fraterculus (Wiedemann) (Diptera, Tephritidae) e desenvolvimento larval em frutos de duas cultivares de quiviseiro (Actinidia spp.). Revista Brasileira de Fruticultura, 34(1), 67-76. https://doi.org/ 10.1590/S0100-29452012000100011

Machota Junior, R., Bortoli, L. C., Cavalcanti, F. R., Botton, M., \& Grützmacher, A. D. (2016). Assessment of injuries caused by Anastrepha fraterculus (Wied.) (Diptera: Tephritidae) on the incidence of bunch rot diseases in table grape. Neotropical Entomology, 45(4), 361-368. https://doi.org/10.1007/s13744-0160377-y

Majdoub, O., Dhen, N., \& Salaheddine Souguir, U. (2014). Chemical composition of Ruta chalepensis essential oils and their insecticidal activity against Tribolium castaneum. Tunisian Journal of Plant Protection, 9(1), 83-90.

Marangoni, C., de Moura, N. F., \& Garcia, F. R. M. (2013). Utilização de óleos essenciais e extratos de plantas no controle de insetos. Revista de Ciências Ambientais, 6(2), 92-112.

Monteiro, L. B. (2004). Fruteiras de caroço: Uma visão ecológica. UFPR, Departamento de Fitotecnia e Fitossanitarismo, Departamento de Solos e Engenharia Agrícola.

Nava, D. E., \& Botton, M. (2010). Bioecologia e controle de Anastrepha fraterculus e Ceratitis capitata em pessegueiro. Embrapa Uva e Vinho-Documentos (INFOTECA-E).

Nguyen, V. L., Meats, A., Beattie, G. A. C., Spooner-Hart, R., Liu, Z. M., \& Jiang, L. (2007). Behavioural responses of female Queensland fruit fly, Bactrocera tryoni, to mineral oil deposits. Entomologia Experimentalis et Applicata, 122(3), 215-221. https://doi.org/10.1111/j.1570-7458.2006.00504.x

Nunes, M. Z., Boff, M. I. C., dos Santos, R. S. S., Franco, C. R., \& da Rosa, J. M. (2015a). Control of the South American fruit fly in pear with natural-based products. Comunicata Scientiae, 6(3), 344-349. https://doi.org/10.14295/cs.v6i3.863

Nunes, M. Z, Boff, M. I. C, dos Santos, R. S. S., Franco, C. R., Wille, P. E., Rosa, J. M., \& Amarante, C. V. T. 2015b. Damage and Development of Anastrepha fraterculus (Diptera: Tephritidae) in Fruits of Two Pear Cultivars. Agrociencia Uruguay, 19(2), 42-48.

Oliveira, W. A. D., Pereira, F. D. O., Luna, G. C. D. G. D., Lima, I. O., Wanderley, P. A., Lima, R. B. D., \& Lima, E. D. O. (2011). Antifungal activity of Cymbopogon winterianus Jowitt ex Bor against Candida albicans. Brazilian Journal of Microbiology, 42(2), 433-441. https://doi.org/10.1590/S1517-83822011000200004

Oliveira, F. Q. de. (2014) Associação de variedades de goiaba, bioinseticidas e o parasitóide Diachasmimorpha longicaudata no controle de Anastrepha fraterculus (Doctoral dissertation, Universidade Estadual Paulista Júlio de Mesquita Filho, SP, Brasil). Retrieved from https://repositorio.unesp.br/handle/11449/113994 
Oviedo, A., Van Nieuwenhove, G., Van Nieuwenhove, C. \& Rull, J. (2018). Biopesticide effects on pupae and adult mortality of Anastrepha fraterculus and Ceratitis capitata (Diptera: Tephritidae). Austral Entomology, 57(4), 457-464. https://doi.org/10.1111/aen.12296

Pinheiro, P. F., Queiroz, V. T. D., Rondelli, V. M., Costa, A. V., Marcelino, T. D. P., \& Pratissoli, D. (2013). Insecticidal activity of citronella grass essential oil on Frankliniella schultzei and Myzus persicae. Ciência e Agrotecnologia, 37(2), 138-144. https://doi.org/10.1590/S1413-70542013000200004

Rattanapun, W., Amornsak, W., \& Clarke, A. (2009). Bactrocera dorsalis preference for and performance on two mango varieties at three stages of ripeness. Entomologia Experimentalis et Applicata, 131(1), $243-253$. https://doi.org/10.1111/j.1570-7458.2009.00850.x

Rosa, J. D., Boff, M. I. C., Gonçalves, P. A., Boff, P., \& Nunes, M. Z. (2013). Andiroba oil (Carapa guianensis Aubl) in the capture of the fruit fly (Anastrepha fraterculus Wiedemann) in Feijoa (Acca sellowiana (Berg) Burret). Idesia, 31(3), 97-102. https://doi.org/10.4067/S0718-34292013000300013

Ruiz, M. J., Juárez, M. L., Alzogaray, R. A., Arrighi, F., Arroyo, L., Gastaminza, G., ... Vera, T. (2014). Toxic effect of citrus peel constituents on Anastrepha fraterculus Wiedemann and Ceratitis capitata Wiedemann immature stages. Journal of Agricultural and Food Chemistry, 62, 10084-10091. https://doi.org/10.1021/ jf503063b

Schlesener, D. C. H., Nunes, A. M., Cordeiro, J., Gotts-Chalk, M. S., \& Garcia, F. R. M. (2014). Mosca-da-cereja: Uma nova ameaça a fruticultura brasileira. Cultivar $H F, 12,6-8$.

Silva, P. G., Castro, M. J., Silva, P. H., Lima, K. O., \& Oliveira, M. R. (2014). Efeito do óleo essencial de citronela sobre a mortalidade e oviposição do caruncho do feijão-caupi. Embrapa Meio-Norte-Resumo em anais de congresso (ALICE). Congresso Brasileiro de Entomologia, Goiânia, Entomologia Integrada à Sociedade Para o Desenvolvimento Sustentável. Anais... Goiânia: Sociedade Entomológica do Brasil.

Soares, C. G., de Lemos, R. N. S., Cardoso, S. R. S., Medeiros, F. R., \& Araújo, J. R. G. (2008). Efeito de óleos e extratos aquosos de Azadirachta indica A. Juss e Cymbopogon winterianus Jowitt sobre Nasutitermes corniger Motschuls (Isoptera: Termitidae). Revista de Ciências Agrárias/Amazonian Journal of Agricultural and Environmental Sciences, 50(1), 107-116.

Teixeira, R. (2009). Métodos alternativos para o manejo de Anastrepha fraterculus (Wied.) em pomares de maçã e sua influência sobre a qualidade dos frutos (Master's thesis, Universidade do Estado de Santa Catarina, Santa Catarina, Brasil). Retrieved from http://www.tede.udesc.br/handle/tede/1263

Treichel, M., Kist, B. B., dos Santos, C. E., de Carvalho, C., \& Beling, R. R. (2016). Anuário brasileiro da fruticultura. Santa Cruz do Sul, RS: Editora Gazeta. Retrieved February 10, 2018, from http:/www.editoragazeta.com.br/produto/anuario-brasileiro-da-fruticultura-2016

Vásquez-Morales, S. G., Flores-Estévez, N., Rafael, L., Sánchez-Velásquez, M. D. R. P., \& López, H. V. (2014). Bioprospecting of botanical insecticides: The case of ethanol extracts of Magnolia schiedeana Schltl. applied to a Tephritid, fruit fly Anastrepha ludens Loew. Journal of Entomology and Zoology Studies, 3(1), 01-05.

Zucchi, R. A. (2008). Fruit flies in Brazil-Anastrepha species and their host plants and parasitoids. Retrieved February 10, 2018, from www.lea.esalq.usp.br/anastrepha

\section{Copyrights}

Copyright for this article is retained by the author(s), with first publication rights granted to the journal.

This is an open-access article distributed under the terms and conditions of the Creative Commons Attribution license (http://creativecommons.org/licenses/by/4.0/). 